\title{
THE SUCCESSION OF NEW STATES TO MULTILATERAL TREATIES
}

\author{
OKON UDOKANG, Ph.D."
}

Based on historical data, the author enunciates as a general theme that there is a clear tendency for new States to acknowledge the continuity of Multilateral Conventions of economic, administrative, and humanitarian importance. Alternative theories of succession, namely the cleanslate theory, the contract theory, and the legislative theory are examined by the author by way of introduction. The practice of new States regarding succession to Multilateral Conventions as well as Treaties, of which the Secretary-General of the United Nations is depository, is discussed by the author. Dr. Udokang analyzes the new State's practices by referring to certain international organizations, notably, the International Labor Organization, the International Monetary Fund, the International Bank for Reconstruction and Development, the International Civil Aviation Organization, the General Agreement on Tariffs and Trade, as well as some less well known Conventions. Throughout, the author attempts to show to what extent economic, political and strategic considerations may influence a State's attitude and ultimate action regarding succession to a Multilateral Convention.

\section{INTRODUCTION}

There seems to be a general inclination on the part of the new States to acknowledge succession to certain multilateral conventions of economic, administrative and humanitarian importance. Theoretically, this furnishes a strong ground for the oft-asserted proposition that multilateral treaties of "a legislative character" devolve automatically upon a new State, or at least should be so regarded on account of the specific legislative element in such instruments. Thus, Dr. Jenks, in an authoritative article on "State Succession in Respect of Lawmaking Treaties", reaches the conclusion that "just as treaty provisions creating local obligations are to be regarded as having the character of executed conveyances rather than that of contractual provisions which continue to be executory, so obligations under legislative instruments should be regarded as obligations under the law rather than as contractual obligations".' In his view, the sociological facts of contemporary international life have brought about revolutionary changes in the subject-matter of international law which, coupled with "the economic and strategic need of an industrialized world community", prompts the view that the traditional doctrine that a new State starts life with a clean slate in so far as the treaty obligations of its predecessor are concerned is no longer adequate for the mid-twentieth century world. On the contrary, "the widely felt and urgent needs of developing international society, both its authority as a legal system and the prospect of developing a peaceful international order" favour the contention that multilateral "law-making" treaties survive changes of sovereignty." He further argues that if the principle is accepted that a new State is bound by existing rules of customary

- B.A. (California State College), M.A. (Howard University). Ph.D. (University of Aiberta). The following article is an excerpt lrom the author's Doctoral thesis. other chapters of which are being published by the Canadian and the Archiv des national Law.

C. Wilfred Jenks, State Succession in Respect of Law-making Treaties, (1952) 29 B.Y.I.L. at 142.

: Id., at 108 and 110. 
international law, there is no reason why, "now that the rules established by multipartite legislative instruments constitute so large a part of the operative law of nations, a new State should be regarded as starting with a clean slate in respect of rules which have a conventional rather than a customary origin"." This argument merely assumes that "multipartite legislative instruments" are the same as customary international law, and hence automatically binding upon all new members of the international society. What seems to be ignored is the fact that a treaty-whether bilateral or multilateral-is a contract and is binding only upon parties to it.

Professor O'Connell, while recognizing the desirability of continuity of treaty obligations, criticizes Jenks' criterion of transmissibility on the ground that the concept of multi-lateral "legislative" treaty is somewhat misleading. In his view, "a treaty, no matter what its form or subject-matter, is always a contract, and the problem is one of succession to contractual rights and duties rather than birth into a legislative regime". A treaty may be described as "law-making" when it is binding not only upon its parties but also upon nonsignatories; in that case, "it is not the treaty itself which creates the law ... but the transformation of its essential provisions into normative customs":" Accordingly, he maintains that treaties devolve "not because of their legislative characteristics, but because of their subject-matter"."

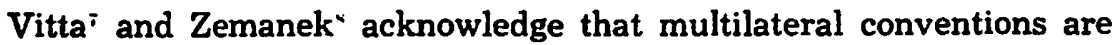
increasingly being regarded as legislative on account of the normative character of the rules they create, but doubt that even so they are kinding on non-parties. Zemanek insists that the principle of mutuality is essential to all treaty-making; the notion of automatic succession, therefore, constitutes a violation of this principle." Bartos recognizes the general trend towards succession, but maintains that the new State must retain the right of option." Dr. Zourek states that since 'every sovereignty is obtained in an original way ... the rights and (ibligations of the predecessor emanating from international law, cannot pass on the newly emerging State, unless such new State takes them over by its own decision, or unless it can be proved that it is (ibliged to assume them under general international law"."

Seeing that there is a clear tendency for new States to acknowledge the continuity of multilateral conventions, one may be tempted to clismiss the above arguments as largely a quarrel over words, yet this would in no way resolve the problem. What is at stake is more than just a question of terminology, for it may well impinge upon an important principle of treaty law, namely, that a treaty, being based upon agreement, cannot affect the law which applies to States which do not become parties to it. This is the rule, pacta tertiis nec nocent nec prosunt, and it applies not only to bilateral treaties but also to

3 Id.p at 107.

4 OConnell. State Succession, Vol. 2 (1967) at 213.

5 Id., at 212 .

i) Jitia, annuaire francais, (1960) at 225-228.

* Zemanek. State Succession after Decolonisation, (1965) 116 Hague Recueil at 187 et seq.

10 Ud.N. Doc. A/CN.4/160. Annex II. Appendix, at 15.

11 Zourek. The Effect of Independence on Treaties, (1965) I.L.A. at XV. 
multilateral conventions. The concept of a "legislative multilateral instrument" would seem to imply an exception to this rule. Writing on the general problem posed by the notion of international legislation to the task of developing and codifying international law, Professor Jennings states that: ${ }^{12}$

there is no authoritative body which can lay down general norms not sanctioned by the common agreement of States ... The all too common use of the term 'international legislation' 13 in connexion with general treaties is therefore to be deplored; for not only does it give an altogether misleading impression of the condition of the international society, but it further tends to propagate a dangerous complacency by obscuring one of the most obstinate of the difficulties with which the international lawyer has to contend. The truth of the matter is that the general law-making treaties differ from particular treaties only in degree and not in kind. Even the general treaty is law only for the parties to it.

This general position of the law requires the qualification that, although a treaty, whether bilateral or multilateral, is binding only on the parties to it, third States not parties to the treaty will be bound by identical rules if in fact it is declaratory of existing customary law." But, as already pointed out, the rules so declared derive their binding force not from the treaty itself but from customary law. Those committed to the negative school of thought, perhaps basing their contention upon the traditional view of the law, consistently argue that in so far as the succeeding States are concerned, treaties of their predecessors are res interalios acta. ${ }^{33}$ It appears difficult, however, to state with finality any specific legal doctrine which could be said to be accepted by the new States as a common guide to the problem of succession to multilateral treaties. Since multilateral conventions are often open to accession, it is not uncommon for the new States to deposit instruments of accession to such conventions, thus sidestepping the whole issue of succession. This in their view would seem to signify expression of their free will, as sovereign States, to be bound by such treaties. on other occasions, it is equally common for a new State to declare itself a successor in principle to its predecessor's rights and duties arising under multilateral conventions which were applied to its territory while it was still dependent. For the practice of the new States, we shall now turn to international conventions of which the Secretary-General of the United Nations is the depositary.

\section{SUCCESSION TO MULTILATERAL CONVENTIONS OF WHICH THE SECRETARY IS DEPOSITARY}

In the practice of the United Nations, the Secretary-General, in exercising the depositary functions, has allowed himself to be guided chiefly by the relevant provisions of the specific international conventions in inviting a new State to become a party to such conventions. Some of the agreements contain territorial application clauses, but these vary from convention to convention. While some provided for optional application of the convention to the former colonies of the

12 Jennings The Progessive Development of International Law and Its Codification, (1947) 24 B.Y.I.L. at 304 .

is See Hudson. International Legislation, Vol. I at XIII, where he defines "international legislation" as "the process and the product of the consclous elfort to make additions to, or changes in. the law of nations".

1t Jennings. supra., n. 12 .

15 Castren. Obligations of States arising from the Dismemberment of Another State, (1951) 13 Zeitschrift fur Austlandisches Recht und Volkerrecht at 753-754: Lester. (1963) 12 I.C.L.Q. at 475 et. seq.. 
predecessor States, others provided for optional exclusion of such territories from the application of the convention. Still others made the application of such conventions in the territory of the non-metropolitan State dependent on whether or not the previous consent of that territory was required by domestic law. ${ }^{10}$ This posed no small problem to the depositary with regard to the formulation of a definitive policy to guide the action of the Secretariat, especially as an increasing number of dependent territories acquired full independence after the Second World War. In 1949, the problem concerning the succession of the emerging States to the multilateral conventions was stated by the Secretariat as follows: ${ }^{17}$

As the protocols amending former conventions provided that they were open for signature only to the States Parties to those conventions, the question has arisen whether the new States should be regarded as Parties to the conventions in virtue of the undertakings assumed by the Powers which were formerly responsible for their administration.

Admittedly, the treaties or instruments establishing the independence of a new State usually deal with the problem of that State's succession to international rights and obligations. Nevertheless, it had to be determined whether the new State had to notify the Contracting Parties expressly in writing that it considered itself bound by the conventions covering those rights and obligations.

Actually, the protocols amending former conventions were signed by the new States to which the conventions were applicable in virtue of declarations made by the Powers which formerly had authority over those territories. In view of the clause limiting to certain States the right to become Parties to the protocols, signature by the new States constituted an implicit acknowledgment vis-a-vis the international community that they regarded themselves as still bound by the conventions in question. In some cases, moreover, an express declaration to this effect was made under the signature of the State concerned.

Clearly, this statement of policy was designed to achieve legal substitution on the widest possible scale, but it was based on no consistent principle as a result of the differing character of the multilateral conventions with which the Secretary-General had to deal. If anything, the depositary's initial approach was based upon a presumption of novation, particularly where the convention in question contained a territorial application clause. Yet, in the last analysis, the SecretaryGeneral acted in deference to the wishes of the new State, for practice was not only based upon "the nature of the clauses in the treaties in question" but also upon "the interpretation placed on those clauses by the parties concerned". ${ }^{1 k}$ The normal procedure is for the SecretaryGeneral to send a list of the multilateral conventions of which he is the depositary to each new State, asking it to declare its attitude. ${ }^{19}$ The purpose of this is to consider each new State as a party in its own name to the treaty concerned. This method has not, however, proved very effective in eliciting the desired response from the new States.

On the other hand, where the treaty contained no territorial application clause, "the depositary has . . . to draw certain conclusions from the nature of the treaty and, if necessary, from the travaux preparatoires, and from practice"." Frequently, action in such cases is based upon the assumption that the treaty was automatically applicable to all dependent territories of every party. In the case of

16 ST/LEG/7, at 47 .

17 U.N. Doc. 1949, V. 9. Signatures, Ratifications, Acceptances, Accessions, etc., covering the Multilateral Conventions and Agreements in respect of which the Secretary General Acts as Depositary, at 3-4.

in ST/LEG/7. at 51 .

i: U.N. Doc. A/CN.4/150. paragraphs 133-134.

$20 \mathrm{ST} / \mathrm{LEG} / 7$, paragraph 88 . 
such treaties, however, it is possible that the new State may decline to recognize itself as bound on the ground that the treaty was never promulgated as part of the internal law of the territory. Thus, in regard to the Convention on the Privileges and Immunities of the United Nations, adopted by the General Assembly on February 13, 1946, and the Convention on the Privileges and Immunities of the Specialized Agencies, adopted by the General Assembly on November 21, 1947, the Secretary-General decided as a matter of principle that, in view of their nature, these Conventions should be regarded as applying to the territories for the international relations of which the acceding States were responsible. Accordingly, in his letter of July 16, 1962, the Secretary-General sent to the Congo (Kinshasa) copies of the instruments by which Belgium had extended to its territory certain treaties on which the Congo had not yet declared its position. But in reply dated May 7, 1962, and received by the Secretary-General on August 13, 1962, the Government of the Republic of the Congo, while acknowledging itself bound by the 1948 Protocol on Drugs, stated in reference to the above mentioned Conventions: "1

The Government of the Congo cannot consider itself bound by the Convention on the Privileges and Immunities of the United Nations.... Although this Convention has been ratified by Belgium, there is no provision in the law of the Congo under which it could be applied to this country. In any event, it does not appear to have been applied to the Congo before the latter attained independence. It does not seem to contain any provision for its automatic entry into force in the dependent territories of acceding States ...

The letter further notified the Secretary-General that research was continuing to ascertain whether the remaining treaties about which the Congo had not yet indicated its position had ever been published by Belgium in the legislation of the Congo. Similarly, the Government of the Ivory Coast, by its letters of May 10, June 22, and December 7, 1961, informed the Secretary-General that Ivory Coast considered itself bound by all the treaties listed with the exception of the 1953 Convention on the Political Rights of Women, because this had never been applied by France to the Ivory Coast. It may also be added that Tunisia, which recognized itself bound by the Convention of July 28, 1951, relating to the Status of Refugees (this having been ratified by France on its behalf on June 23, 1954), and acceded on November 8, 1957, to the Convention on Road Traffic of September 19, 1949, has not considered itself bound by the Convention on the Privileges and Immunities of the United Nations.

In the evolution of the practice of the Secretary-General regarding the succession of new States to the multilateral treaties of which he is the depositary, great importance has come to be attached, for administrative reasons, to any agreements concerning devolution of international rights and obligations which may have been concluded between the predecessor and the successor States as part of the independence arrangements. On attainment of independence such devolution agreements are registered with the Secretariat and published in the United Nations Treaty Series. Not infrequently, as will be shown, the new States have made reference to these agreements in seeking recognition as parties to existing multilateral treaties entered into by

21 U.N. Doc. A/CN.4/150, paragraph 74 
their parent States. Similarly, third States, as, for example, the United States of America, have on certain occasions referred to these agreements as a possible basis on which to treat as operative between themselves and the new States treaties previously concluded with their predecessor States.

Thus Pakistan explicitly relied upon the provisions of the Indian Independence (International Arrangements) Order, 1947, when accepting the terms of the Hague Conventions on Conflict of Nationality Laws and on a Certain Case of Statelessness, and also when signing the Protocol amending the 1923 Convention on the Suppression of Obscene Publications.": Similarly, Ceylon declared on April 1, 1957, that it considers itself to be a party to the International Air Services Transit Agreement "since May 31, 1945 (the date of the United Kingdom acceptance) under the terms of the External Affairs Agreement between the United Kingdom and Ceylon of November 11, 1947"..3

It should be noted, however, that there are other occasions on which successor States give notice that they regard themselves as bound by multilateral treaties concluded by the predecessor States but make no mention of any agreement relating to the inheritance of treaty rights and obligations. Indonesia, for instance, gave notice that she regarded herself as bound by the Berne Copyright Convention, 1890, the Convention on the Protection of Industrial Property and by the Load Line Convention, 1930." Cambodia and Vietnam have acknowledged that they consider themselves bound by the Convention on the Safety of Life at Sea in virtue of its application to Indo-China on November 15, 1938.:" Ceylon stated that it is applying the Dangerous Drugs Convention of 1925," and Malaysia has notified that it considers itself bound by the General Convention on the Privileges and Immunities of the United Nations." ${ }^{2}$ Yet in none of these communications do the new States appear to have made any reference to the terms of the devolution agreements. Indeed, they have not generally filed a uniform acceptance of treaties of which the Secretary-General is the depositary and to which their predecessors were parties. On the whole, they have indicated their willingness to be considered as successors only when specific decisions were called for. An example is when they are asked to become parties to amending protocols. ${ }^{2 \beta}$

Notwithstanding the doubtful legal value of the inheritance agreements in terms of their constitutive effect with respect to succession to treaty rights and obligations, "2" the depositary has utilized them as a significant additional guide in the formulation of the Secretariat's policy respecting the transfer of rights and duties under multilateral convention. In the Summary of the Practice of the Secretary-General as Depositary of Multilateral Agreements, published on August 7,

22 U.K.T.S., No. 6 (1958), Cmnd. 368, at 33 and 34.

23 U.K.T.S., No. 73 (1957), Cmnd. 386, at 2 .

24 U.K.T.S., No. 105 (1951), Cmd. 8447, at 3 and 5: U.K.T.S., No. 6 (1958), Cmnd. 368. at 30 .

2: Ư.K.T.S. No. 105 (1951). Cmd. 8447, at 8.

2* U.K.T.S., No. 73 (1957). Cmnd. 386, at 7 .

28 Id. at 20.

in ST/LEG/7, at 61 .

\#v See, for example, Lauterpacht, State Succession and Agreements for the Inheritance of 'Treaties. (1958) 7 I.C.L.Q at 524-530; MeNair. The Law of Treaties (1961) at 653; Lester in 12 1.C.L.Q. (1963) at 503 et. seq.. 
1959, the policy of the Secretary-General is outlined, inter alia, as follows: ${ }^{30}$

The Secretary-General, in performing his functions as depositary, has paid the closest regard to these clauses (devolution clauses) while respecting the interpretation placed upon them by the parties. In addition, it has been found in practice that most new States acknowledge themselves to be bound by a number of agreements previously applied in their territory by the State formerly responsible for their external relations. This practice, however, has not been uniformly followed; most new States, while acknowledging themselves bound by certain agreements, have formally acceded to others which had also been applied in their territory. The Secretary-General has not felt that as depositary he could refuse to accept such instruments, which are an express manifestation of the new State's will. However, where the treaty of independence contains a devolution clause and this clause is precise, he has inserted in the relevant Secretariat publications, against the name of the new State, a reference to the agreements previously applicable to its territory, and has in such cases invited the Government of the new States to become and has in such cases invited to any protocols amending such agreements. Furthermore, if a precise and explicit devolution clause concerning the rights and obligations arising out of international conventions accepted by the State then responsible for the external relations of the new State's territory is the subject of a specific agreement concluded between the two States concerned, and if that agreement is registered with the Secretariat, the Secretary-General considers the new State to be bound by such conventions without having to transmit any notification on the subject. Moreover, the publication of the devolution agreement in the United Nations Treaty Series and the inclusion of the new State in the Secretariat publication Status of Multilateral Conventions among the States parties to conventions previously applied in its territory gives the States concerned all the information they require.

While the existence of a devolution agreement may permit an attitude favorable to automatic novation, the policy of the Secretariat is flexible enough to allow each case to be dealt with on an ad hoc basis. This appears to be supported by the varied forms of standard letter which the Secretary-General writes ${ }^{31}$ to each new State on admission to membership in the United Nations, inviting it to notify its position regarding the treaties of which the U.N. is the depositary. It is submitted that the wide latitude allowed the new States to declare their attitude towards succession to multilateral treaties results not from the application of a general rule of international law, but rather from the absence of any such rule. Furthermore, it reflects the predisposition of the Secretariat to respect the sovereignty of the newly independent State.

\section{PRACTICE OF THE NEW STATES WITH REGARD TO TREATIES OF WHICH THE SECRETARY-GENERAL IS DEPOSITARY}

The pattern of practice of the new States regarding succession to these treaties is undulatory. While the majority of them are favorably disposed towards succeeding or acceding to existing multilateral treaties, and are generally encouraged by the Secretary-General to do so, their choice of the treaties would appear to be purely a matter of interpretation, which no doubt involves a certain degree of arbitrariness. Thus a new State's specific attitude may be said to be motivated as much by a wide diversity of political considerations as by the humanitarian, technical or administrative character of the treaty in

31) ST/LEG/7, at 61-62.

31 See U.N. Doc. A/CN.4/150; I.L.C. Yearbook (1962). Vol. 2, at 122. 
question. Even when Algeria, ${ }^{3:}$ Upper Volta ${ }^{3: 5}$ and Israel ${ }^{34}$ have explicitly opted for the clean slate principle, they have in practice acknowledged the continuity of certain conventions which were applied to their territory. Algeria has acceded to eleven of the twenty-five multilateral conventions ratified on her behalf by France. Upper Volta in a letter to the Government of Switzerland, as depositary of the four 1949 Geneva Conventions for the protection of war victims, a copy of which was transmitted to the Secretary-General of the United Nations, declared that the four Conventions "apply by law to the territory of the Republic of the Upper Volta in virtue of their ratification by France on June 28, 1951".35 Israel informed the Secretary-General that its policy is "based upon non-recognition by the Government of Israel of any automatic "succession" to the treaty obligations of Palestine, coupled with a willingness to examine that treaty position and to accede de novo to such international treaties as were found to be appropriate, whether or not the mandated territory of Palestine was previously bound by them".3:

The Central African Republic, Congo (Brazzaville), Ivory Coast, Ghana, Malaysia (formerly Malaya), Morocco, Nigeria, Sierra Leone, Syria and the U.A.R. have all accepted succession in principle, but have in practice only done so in relation to specific conventions.:" On the other hand, Cameroon, Congo (Kinshasa), Cyprus, Dahomey, Guinea, Malagasy Republic, Mali, Senegal, Tanganyika (now Tanzania), Togo and Tunisia, while acknowledging succession to only some of the applicable conventions, have in other cases chosen to accede to those conventions which had been extended to their territories by their predecessor States." Somalia," Mauritania," Gabon" and Chad": have so far declared no position of principle concerning succession to the multilateral conventions of which the Secretary-General is the depositary. But they all have recognized that they continue to be bound by certain conventions of the International Labour Organization.

After the formation of the United Arab Republic by the Union of Egypt and Syria, following the plebiscite of February 21, 1958, the Foreign Minister of the Republic in a communication to the SecretaryGeneral, dated March 1, 1958, declared: ${ }^{13}$

It is to be noted that the Government of the United Arab Republic declares that the Union is a single Member of the United Nations, bound by the provisions of the Charter, and that all international treaties and agreements concluded by Egypt or Syria with other countries will remain valid within the regional limits prescribed on their conclusion and in accordance with the principles of international law.

32 See Algerian Delegate's statement. GAOR, 17th Session, 6th Committee, 742nd Meeting, paragraph 14.

33 U.N. Doc. A/CN.4/150, paragraph 111.

31 U.N. Doc. A/CN./19; I.L.C. Yearbook, (1950), Vol. 2, at 206-218; U.N. Doc. A/CN.4/150, at 110 , parasraph 30 .

35 U.N. Doc. A CN.4/150, at 119, paragraph 112.

34i ST/LEG/SER.B/14, at 42, paragraph 11.

At least in connection with war criminals, which perhaps provided a basis for the trial of Eichmann, it has been observed that the contention of retroactive legislation could be rejected on the ground that "Israel is in fact a successor to the Mandatory Power in Palestine and, therefore. far from creating new rights for herself after the commission of the offences, she was merely taking over rights herselu arter the commision of the oxtsen, Green. The Maxm Nullum Crimen Sine Lege and the Eichmann Trial, (1962) 38 B.Y.I.L. at 465-466.

37 I.C.L. Yearbook, (1962) Vol. 2, at 109 et. seq.

36 U.N. Doc. A/CN.4/150.

39 Id., at paragraph 106.

to Id., at parasraph 114.

+1 Id., at paragraph 81 .

42 Id., at parasraph 65.

43 Id., at paragraph 48. 
On the strength of this letter, the Secretary-General listed the U.A.R. in the Status of Multilateral Conventions ${ }^{14}$ as a party to all the treaties to which Egypt or Syria had been parties before the Union was established. Under the name of the Republic, it was shown whether Egypt or Syria or both had taken action regarding the treaty in question.

At the time of her independence, Indonesia entered into a devolution agreement with the Netherlands. This came into force on December 27, 1949. On admission to the United Nations, on September 28, 1950, it addressed a note to the Secretary-General, acknowledging "that the rights and obligations of the Kingdom of the Netherlands arising out of the signature or acceptance of the following Protocols to the General Agreement . . . are to be considered as rights and obligations of the Republic of Indonesia inasmuch as such Protocols are applicable to the jurisdiction of the Republic of Indonesia." In a subsequent note to the Secretary-General, dated February 26, 1959, Indonesia listed among others the following agreements which she considered binding on her: Convention Providing for a Uniform Law for Cheques, ${ }^{\text {th }}$ Convention for the Settlement of certain Conflicts of Laws in connection with Cheques,"i and Convention on the Stamp Laws in connection with Cheques, ${ }^{42}$ all signed on March 19, 1931, at Geneva. On the other hand, Indonesia, in a note verbale of September 16, 1959, was to declare, in respect of the Protocol, signed at the Hague on April 12, 1930, relating to Military Obligations in Certain Cases of Double Nationality ${ }^{10}$ that: ${ }^{\text {so }}$

The Republic of Indonesia is however of the opinion that all agreements signed by the Netherlands on behalf of or declared to be valid for the former Netherlands East Indies do not automatically apply to the Republic of Indonesia as a successor of the former Netherlands East Indies. The Republic of Indonesia therefore does not consider itself bound by said Protocol.

Other multilateral conventions whose applicability to Indonesia has not been acknowledged include: the Convention for the Suppression of the Manufacture of Opium, 1925; International Opium Convention, 1925; Distribution and Manufacture of Narcotics Convention, 1931; Obscene Publications Convention, 1910 and 1923; Slavery Convention, 1926; White Slave Traffic Conventions, 1904, 1910, 1921, 1933; and the Economic Statistics Convention of 1928. What is responsible for this discriminatory, seemingly contradictory, policy towards succession to multilateral conventions, even with the existence of a devolution agreement? There is little doubt that Indonesia has tended to apply its inheritance agreement in acknowledging succession to certain international treaties when this has suited its political and economic objectives, but the overall tendency of its policy is pre-eminently in the direction of non-succession. The unequivocal rejection of the concept of automatic succession in the foregoing statement by Indonesia would appear to indicate that even the existence of an inheritance agreement cannot lead lightly to a presumption of automatic subrogation.

it U.N. Doc. ST/LEG/3/Rev. 1 .

t5 U.N. Doc. A/CN.4/150; Yearbook of the I.L.C., (1962) Vol. II. at 110 to 11 ; ST/LEG/7, at 56 .

is L.N.T.S.. Vol. 143, at 355 .

17 L.N.T.S., Vol. 143, at 407.

it Id., Vol. 143, at 7 .

so U.N. Doc. A/CN.4/I50, paragraph 21; see also U.N.T.S., Vol. 69, at 3. 


\section{SUCCESSION TO I.L.O. CONVENTIONS}

The practice of the International Labour Organization (I.L.O.) regarding the succession of the new States to international labour conventions has crystallized during the more than twenty years of its existence, and is probably the most consistent of all the international organizations. Strangely enough, when the I.L.O. Constitution was amended in 1946, no provision was made regarding the admission of new States to which international labour conventions had been applied, despite the fact that some colonial territories were already on the verge of achieving full independence. Article 35(1) of the Constitution of the I.L.O. merely provided that "The Members undertake that Conventions which they have ratified in accordance with the provisions of this Constitution shall be applied to the non-metropolitan territories for whose international relations they are responsible, including any trust territories for which they are the administering authority, except where the subject-matter of the Convention is within the self-governing powers of the territory or the Convention is inapplicable owing to the local conditions or subject to such modifications as may be necessary to adapt the Convention to local conditions". Paragraphs 2 to 6 of the same article detailed further procedures by which international labour conventions could be made applicable in such territories. However, with the emergence of a large number of new States, the I.L.O. has made great efforts to ensure the continued application to such States of the labour conventions which had been previously applied in their territory.

In 1951, the International Labour Conference stated that: ${ }^{\text {o1 }}$

In a number of cases Conventions are regarded as binding on Members of the Organization in virtue of the principle of State Succession .... In so far as they may involve any qualifications of the ordinary rules in regard to State Succession they tend to suggest that there are special considerations which give international labour conventions a more durable character than treaty engagements of a purely contractual nature.

Although this statement in itself has no obligatory force, it seems to represent the growing concern of the Organization with the pressing problem of State succession as a result of the rise of a large number of new States after the Second World War. The I.L.O., deeply committed to the promotion of social justice as embodied in the Preamble to its Constitution, recognizes that an abrupt discontinuity of relevant labour conventions in the territory of a new State on account of its newly acquired sovereignty would indeed be detrimental to the concept of human rights. The view favouring continuity of such conventions irrespective of change of sovereignty is made necessary in view of the wide network of multilateral treaties administered by the Organization. Some 116 conventions affected the former colonial territories, and by 1961 the International Labour Office had been notified of about 3,223 territorial applications, 290 of which had been modified in accordance with the provisions of Article 35 of the I.L.O. Constitution. 32

The question of succession to international labour conventions began in 1937 with the separation of Burma from India. Burma, though not

51 Explanatory Note, The International Labour Code 1951, (1952) Vol. 1 at XCVIII.

i2 O'Connell. Independence and Succession to Treaties, (1962) 38 B.Y.I.L. at 139; Jenks in (1952) 29 B.Y.I.L. at 135-136: Wolf, Anruaire Francais (1961) at 742-751. 
a non-metropolitan territory within the meaning of Article 35 of the Constitution of the I.L.O., was separated from India on April 1, 1937.5.7 It was then administered by the United Kingdom until October 17, 1947, after which it applied for admission to membership in the I.L.O. At the International Labour Conference of June 1937,"3t the British delegate stated that Burma had now acquired an international status similar to the self-governing territory of Southern Rhodesia, although she still remained an overseas territory of His Majesty. Accordingly, it was notified that Burma would continue to observe and apply all the international labour conventions in which she previously participated as part of India. This position seems to have been accepted by the other delegates to the Convention. However, by a letter of April 19, 1948, the Foreign Affairs Minister of Burma notified the I.L.O. that Burma recognized "that the obligations resulting from the international labour conventions ratified in respect of Burma by India prior to April 1, 1937 continue to be binding upon the Union of Burma in accordance with the terms thereof".s.

Similarly, after Pakistan seceded from India, by the operation of the Indian Independence Act, 1947, in she acknowledged herself bound by the international labour conventions which had been ratified by India prior to August 14, 1947::- Following this, Syria, the Philippines, Lebanon, Jordan, Sudan, Kuwait and Israel were admitted to membership in the I.L.O., but Israel made it clear that, as a totally new State, she started life completely free of all obligations, owing to the special circumstances under which she had attained her international personality." Ceylon's application for membership also contained an acceptance of the undertaking regarding the application of international labour conventions which had been extended to her territory by the United Kingdom, and further promised to give early consideration to the formal ratification of the relevant conventions covered by the

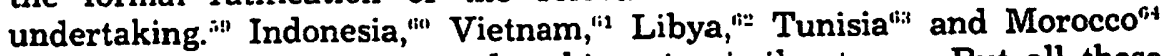
in their applications gave undertakings in similar terms. But all these statements of principle implied no specific obligation on the part of the States; they merely indicated that the new States were willing to apply those labour conventions which had previously been applied in their territory by the predecessor States.

It was then thought necessary to devise a formula whereby a declaration of continuity of I.L.O. Conventions could be secured from a new State on being admitted to membership in the Organization. Under this rule, Ghana, which acceded to independence on March 6, 1957, was admitted in the latter part of that year to membership in the I.L.O. ${ }^{6 i}$ In the form letter, besides indicating the number of I.L.O. Conventions by which they acknowledge themselves to be bound, the new States also

58 Government of India Act, 1935, 26 Geo. V. c. ${ }^{2}$.

ss I.L.o. Official Bulletin, Vol. XXXI, No. 3. December 31, 1948, at 217.

86 io and 11 Geo. VI. c. 30 .

67 J.L.O. Official Bulletin, Vol. XXX. No. 5 (1947) at 334.

88 Rosenne. Israel et les traites internationaux de ia Palestine, (1950) Journal du droit international at 1140

69 1.L.O. Official Bulletin, vol. XXXI. No. 3 (1998) at 223.

60 J.L.O. Official Bulletin. Vol. XXXIII. No. 2 (1950) at 67.

61 Id., Vol. XXXIII, No. 5 (1950) at 248-251.

62 Id. Vol. $X \times X V$, No. 2 (1952) at 85

6 Id., Vol. XXXIX, No. 2 (1956) at 67-68.

as Id. Vol. XXXIX. No. 2 (1956) at 68-69.

os Id., Vol. XL, No. 8 (1957) at 373 . 
undertake to continue to apply certain specified conventions which had been declared to be applicable exclusively in "non-metropolitan territories". The conventions are not equally relevant to all the new States. On the contrary, the nature of choice appears to be dictated by the peculiar needs and conditions of a given territory. For instance, while Ghana undertook to continue to apply "the Right to Association Convention, 1947" (non-metropolitan territories), and "Labour Inspectorates Convention", the Federation of Malaya (now Malaysia) undertook to continue to apply only the "Labour Inspectorates Convention". This approach seems to have been followed by all the other new States which gained their independence in the 1960's. It is to be noted, however, that those convention which were expressly intended for non-metropolitan territories can be applied by a new State, since it is no longer a non-metropolitan territory, only as a transitional measure, until such a period that it is in a position to ratify the corresponding convention formerly restricted to the metropolitan countries.

In so far as the succession of the new States is concerned, three classes of the I.L.O. Conventions appear to be involved. The first category includes those which the successor State is required to continue to apply; secondly, those which were modified by the administering authority, but which the successor State must undertake to continue to apply, pending ratification of the "metropolitan" conventions; and thirdly, those intended to maintain "the status quo", undertaking to ratify the convention in full at a later date, particularly if modifications had been reserved.

The above survey shows how the International Labour Organization has sought, as a matter of deliberate policy, to ensure that the continuity of its conventions is not adversely affected by change of sovereignty within the former territories of the colonial authorities. Owing to the underlying humanitarian interests in these conventions, the new States themselves appear to be quite favourably disposed towards this policy. The attitude of the new States was underlined by the expression of support for the I.L.O. practice contained in the resolution adopted at the First Regional Conference of the I.L.O., held at Lagos, Nigeria, in December, $1960.0^{\circ i}$

In spite of the somewhat inflexible approach of the I.L.O. to the question of succession, not all new States were willing to make unreserved declarations of continuity. It is well-known that Uganda and Malawi, in keeping with their general temporizing policy regarding succession to treaty obligations of their predecessor, exhibited great reluctance to abide by the accepted practice. It was not until the I.L.O. Committee of Experts on the Application of Conventions and Recommendations brought pressure to bear that Malawi gave assurances of her intention to remedy the situation." It needs also to be added that even those new States, which anxiously declared in their letters of application the continuity of I.L.O. Conventions in their territory, have in practice accepted some of those conventions on a selective basis. This would appear to indicate that, in the final analysis, the choice of those

(i*: D. Marchand, State Succession and Protection of Human Rights, (1967) 8 Journal of the International Commission of Jurists at 47-48.

i: See Wolf, In Annuaire Francais (1961) at 742 and following.

ii St:e I.L.O. Report of the Committee of Experts, Report III. Part V. International Labour Conference, 49th sess., Geneva (1965) at 23-24. 
conventions is still seen by the new State as a question of policy. This prompts the conclusion that the initial declaration of continuity may well be motivated by a new State's desire to achieve international recognition and acceptance.

\section{SUCCESSION IN RESPECT OF THE INTERNATIONAL MONE- TARY FUND AND INTERNATIONAL BANK FOR RECON- STRUCTION AND DEVELOPMENT}

Properly speaking, the problem of State succession in respect of the IMF and the IBRD appears to be inextricably connected with the question of membership in those organizations. In this sense, obligations arising under their constituent instruments are necessarily obligations incidental to membership in the organizations, and must be distinguished from obligations deriving from other categories of "law-making" multilateral conventions. ${ }^{\text {"3" }}$ It is as well to note that the principle is generally accepted that membership in an international organization, being determined by the rules of its constitution, cannot pass to a successor State."11 But, broadly viewed, whether or not succession occurs remains a question of the interpretation of the relevant constitutional provisions of the organization concerned.

The International Monetary Fund is only peripherally affected by the problem of State succession in so far as territorial changes of member States might imply changes in their voting rights." Article $20(2)(\mathrm{g})$ of the Articles of Agreement of the IMF provides:

By their signature of this Agreement, all governments accept it both on their own behalf and in respect of all their colonies, overseas territories, all territories under their protection, suzerainty, or authority, and all territories in respect of which they exercise a mandate.

Since membership is associated with certain voting rights together with the quota and borrowing privileges, it follows that any constitutional changes of a radical kind within a State member are likely to have some effect on the character of thbse rights. Consequently, the Fund is required to take notice of any such changes in so far as they touch upon the status of a member State. In general, where the problem of succession is involved, the I.M.F. has allowed itself to be guided by the action of the United Nations. When India was partitioned, she transmitted a copy of her devolution agreement to the Fund, and, taking cognizance of the United Nations decision concerning India's membership, the Fund's Committee on membership recommended to the various Governments that India be treated as British India and hence as the original member of the Fund. Thus India's existing quota rights were maintained. On the other hand, Pakistan was required to apply for membership in accordance with the terms and conditions of the Membership Resolution of February 1, 1950. Pakistan's quota was then determined independently by the Board of Governors of the I.M.F.':

In the case of the formation of the United Arab Republic by the Union of Egypt and Syria in 1958, the problem arose as to the substitu-

1:0 Jenks, State Succession in Respect of Law-Making Treaties, (1952) 29 B.Y.I.L. at 133.

i1) Cf. U.N. Opinion in the case of India and Pakistan. GAOR. 2nd sess., ist Cmttee. p. 582, Annex 14g; U.N. Doc. A/CN.4/149, at 8; U.N. Doc. A/C1/212.

i1 Aufricht. State Succession under the Law and Practice of the International Monetary Fund, (1962) 11 I.C.L.Q. at 154-162.

72 I.M.F. Summary of Proceedings, (1950) 5th Annual Meeting of the Board of Governors at 51 . 
tion of the U.A.R., a single member, for the originally separate membership of Egypt and Syria. This, of course, involved a re-assignment of voting rights.": Egypt as a single member of the Fund possessed 850 votes, while Syria had only 315 . The question was whether the combined figure of 1165 votes should be assigned to the U.A.R. or whether an entirely new number of votes should be fixed. It was, however, decided that the U.A.R., as a single member, should now have 915 votes as against the previous separate voting figures of 850 and 315 . This decision was based upon the provisions of Article 12 (5) (a) of the Fund's Articles of Agreement.i4

The International Bank for Reconstruction and Development works in close co-operation with the I.M.F., and as such its practice coincides with that of the I.M.F.. Under Article 2 (1) (b) of its Constitution, membership of the Bank is restricted to members of the Fund. Thus, in case of State succession, the carrying out of a loan agreement would appear to be governed by the Membership Resolution of the Board of Governors of the Fund. ${ }^{i 3}$ Nevertheless, obligations of members in the Bank have no direct connection with those of members of the Fund, even though under the terms of Article 2(1) (a) of the Articles of Agreement "The original members of the Bank shall be those members of the International Monetary Fund". Many of the new States, including Ceylon, Cyprus, Ghana, Indonesia, Israel, Laos, Nigeria, Sudan, Tunisia and Philippines, have joined both the IMF and IBRD since becoming independent. ${ }^{; 6}$

\section{PRACTICE OF INTERNATIONAL CIVIL AVIATION ORGANIZA- TION RESPECTING SUCCESSOR STATES}

The International Civil Aviation Organization came into existence under the authority of the Chicago Convention of December 7, 1944.i Its basic purpose is the regulation of international air traffic. This Convention establishes the international aviation code and stipulates the obligations attaching to membership in the ICAO. Article 2 defines the geographic scope of the operation of the Convention as comprising "the land areas and territorial waters adjacent thereto under the sovereignty, suzerainty, protection or mandate of such a State". No reservation by a contracting State was permitted regarding the exclusion of a dependent territory from the application of the Convention. Thus, the convention as extended by the contracting metropolitan States to all their nonmetropolitan territories. Article 5 of the Chicago Convention lays down that aircraft of a contracting State engaged in non-scheduled international air services have the right to fly over, and to make non-traffic stops in, the territory of any other contracting State. Such aircraft also have the privilege of taking on or discharging passengers, cargo or mail in any contracting State. Similar rights are granted to scheduled flights under Article 1 of the International Air Services Transit Agreement, signed at Chicago on December 7, 1944. Additional privileges are accorded under the terms of Article 1 of the International Air Transport Agreement also concluded on December 7, 1944 at Chicago.

i3.Aufricht, supra, n. 71 at 160; O'Connell, supra, n. 52 at 136.

i. This stipulates that a member shall have 250 votes plus one additional vote for each part of its quota equivalent to 100,000 United States dollars.

is Cf. note 71 above.

it U.N.T.S.. Vol. 15, at 295: Hudson. International Legislation, Vol. 9, at 168. 
Clearly, then, the Chicago Convention on International Civil Aviation is one of those treaties whose scope of operation affects the domestic jurisdiction of many States. Membership in the ICAO can be acquired by mere ratification of, or adherence to, the Chicago Convention in accordance with Article 92. Thus, a new State can become a member of the Organization by filing an instrument of adherence, or of ratification, with the Government of the United States, which is the depositary of the Convention. Adherence to the Convention, however, does not automatically include ratification of the amendments to the Convention which have been approved by the Assembly, and which came into force prior to such adherence. The Secretary-General of the ICAO, on receiving from the depositary notification regarding the adherence of a new State, forwards to such a State certified copies of all protocols of amendments, whether or not in force, requesting the new State to indicate whether it wishes to ratify any or all of the amendments.

The problem of the effect of change of sovereignty upon the air law conventions of the ICAO relates to whether, in view of the extension by the contracting States to the non-metropolitan territories of the Chicago Convention, these air law conventions remain binding upon the new States. Does a new State which previously formed part of the contracting State's territory, after acquiring sovereignty, remain ipso jure a party to the Chicago Convention, and therefore bound by its provisions? The question of succession to these conventions seems particularly important since failure to apply the relevant rules of the conventions in the territory of a new State, even for a short period of time, might well disrupt or hamper the regular functioning of the air services. This would no doubt be the case if a new State previously affected by these conventions, adopted, on achieving independence, the clean slate policy with respect to all the treaty obligations of its predecessor.

Dr. René Mankiewicz, in formerly of the Legal Bureau of the ICAO, maintains "that international air law conventions, including the lawmaking and regulatory decisions of the ICAO Council, are not binding upon a new State unless it has formally consented thereto, either through ratification or by an equivalent formal declaration". Dr. Mankiewicz draws a distinction between "public air law conventions", of which the Chicago Convention is one, and "private air law conventions" such as the Warsaw Convention, 1929, concerned with the unification of rules relating to international carriage by air. The latter (which will be dealt with subsequently in this section) he holds are automatically binding upon a new State, since they entail no international obligation but operate as part of the domestic law of the new State." $\mathrm{He}$ contends that if a new State were automatically a party to the Chicago Convention it would be ipso facto a member of the ICAO, and be obliged to pay its share of the budget of the Organization as assessed by its Council. Furthermore, membership has the effect of imposing certain restrictions upon the rights of a sovereign State. For these reasons, no State should be considered bound without its express consent.

\footnotetext{
ix Manklewicz. Air Law Conventions and the New States, (1963) 29 Journal of Air Law and Commerce at 54 .

il Id., at 62; see also Annuaire Francais de Droit International (1957) at 405-412; Les Nouxeaux Etats et les conventions de droit aerien, (1961) Annuaire Francais at 752.
} 
On the other hand, it is arguable that where treaty obligations are "locally connected" with the whole or portions of a territory, a new State whose sovereignty extends to the areas so affected succeeds to the obligations in question." If therefore the air law conventions are regarded as belonging to the class of international treaties which create local obligations, the successor State, if it wishes to free itself from such obligations, would have to resort to a more formal procedure for terminating the conventions, including denunciation in accordance with the provisions of Article 95 of the Chicago Convention.

There is, however, a tendency on the part of the new States to acknowledge continuity of the conventions. After Pakistan separated from India in 1947, she notified the President of the ICAO Council on August 15, 1947, that "Pakistan has automatically accepted the Civil Aviation Convention, and the Air Transit Agreement, which were ratified by the former Government", in accordance with the provisions of the Indian Independence (International Arrangements) Order of 1947." It stated also that "the successor Government of India (but not Pakistan) continues to enjoy membership of the Council, pending future elections". The ICAO, however, could not accept Pakistan's view since membership in the Organization is virtually synonymous with adherence to the Chicago Convention. Moreover, the ICAO was of the opinion that under the terms of the Indian Independence (International Arrangements) Order, 1947, membership in all international organizations devolves solely upon India. Pakistan, therefore, had to notify the United States Government, as depositary of the Chicago Convention, of its adherence thereto. But Pakistan's adherence did not become effective until the 6th of November, 1947, ninety days after the deposit of its instrument of adherence.

The formation of the U.A.R. on March 25, 1958, made it imperative to re-assess the membership status of Egypt and Syria in the ICAO. In a letter to the Secretary-General of the ICAO, the Minister of Foreign Affairs of the U.A.R.,"' stated that the United Arab Republic should now be treated as a single member of the ICAO and considered bound by the provisions of the Chicago Agreement. Mr. Mohammed Sadek El Karmouty was appointed as the permanent Representative of the U.A.R. and "empowered to participate in all decisions on all matters to be submitted to the Organization". In addition, the letter affirmed: ${ }^{\text {3 }}$

that all agreements, arrangements and obligations existing between the International Civil Aviation Organization on one hand and either Egypt or Syria on the other immediately before the constitution of the United Arab Republic will continue in their terms, Jus Mutatis Mutandis, as if they were agreements, arrangements and obligations duly concluded between the International Civil Aviation Organization and the United Arab Republic.

This communication was followed on May 17, 1958, by a cablegram, confirming the appointment of $\mathrm{Mr}$. Karmouty as the Permanent Representative of the U.A.R. with full powers to take part in the proceedings of the Organization.

bo Oppenheim, International Law, (1955) Vol. I. 8th ed.. at 159 and 165-166.

${ }_{1}$ Section $C$ of this Order stipulates that. except otherwise provided. "rights and obllgations under all international agreements to which India is a party immediately before the appointed day will devolve both upon the Dominion of India and upon the Dominion of Pakistan. and will, if necessary. be apportioned between the two the Dominlon of Pakistan, and will, if necessary, be apportioned between the two Annex 6C.

N: I.C.A.O. Working Paper Al1-WP/23, P/4.

83 Id. 
Having regard to these communications, the decision which the ICAO Council had to take was (a) whether the U.A.R. was a Contracting State, or should be regarded as such; (b) whether the U.A.R. was a member of the Council; and (c) whether the cable of 17th May, 1958, could be accepted as the credentials of Mr. Karmouty as representative of the U.A.R. on the ICAO Council. The Council came to the conclusion that the United Arab Republic, having been established by the Union of two States which had been parties to the Chicago Convention, was to be considered, "for the matters within the competence of the Council", a contracting State and as a member of the Council. But it added that "this decision cannot prejudice the right of the Assembly to determine for itself questions concerning the United Arab Republic in relation to the Organization". ${ }^{+4}$ The Council's decision was transmitted to the Eleventh Session of the Assembly of the ICAO, held in Montreal. On the basis of it, the Assembly accepted the credentials of the U.A.R. delegate, and assessed the contribution of the U.A.R. delegate, and assessed the contribution of the U.A.R. to the budget of the ICAO. ${ }^{\text {.s. }}$

The outbreak of revolution in the Syrian sector of the Repulic led to the dissolution of the Union on September 28, 1961. The ICAO was again confronted with the question of succession with respect to the membership of Syria in the Organization. At the end of September, the Government of Syria sent the following cable to the SecretaryGeneral of the ICAO: ${ }^{\text {Nis }}$

I have the honour to inform you that Syria has been a member of ICAO since 1949 and has been a member thereof jointly with Egypt under the designation: United Arab Republic (Stop) The union having been dissolved on 28 September last the Syrian Arab Republic reassumes its place in ICAO (Stop) I take this opportunity to assure you that the Syrian Arab Republic remains bound mutatis mutandis by all conventions, arrangements and obligations which existed between ICAO and the United Arab Republic in conformity with the Convention on International Civil Aviation (Stop) Please confirm receipt of this cable and transmit copy of the cable to all States members of ICAO (Stop)

Copies of this cable were transmitted to all members of the ICAO Council by its President, who stated that, in the absence of any contrary views, Syria would in future be regarded as a contracting State. November 1, 1961 was set as the deadline for receiving any statements of objection from those member States who might wish to raise such objection. However, no statement of opposition was received by the President. The Council of the ICAO took cognizance of this communication at the Third Meeting of its Forty-fourth Session of that year, and approved the Report of its Finance Committee, re-adjusting the assessments of Egypt and Syria to the budget and the working capital fund of the Organization for the period between September 28 and December 31, 1961. The Council's decision was endorsed by the ICAO Assembly at its Fourteenth Session at Rome in August, 1962.si

The above cases of succession to the Chicago Conventions resulting from the dismemberment of a member State on the one hand, and the federation of a member State on the other, seem to indicate that the attitude taken by the ICAO in each instance was broadly in conformity with the practice of the Untied Nations. It is interesting to note

4 Declaration of March 29, 1958, ICAO Doc. 7878 C/905-18.

s. Resolution A 11-13, ICAO Doc. 7888 A 11-P/12; Doc. 7886 A 11-P/11-2-4

st ICAO Working Paper CWP/3434 and CWP/3449; ICAO Doc. 892C/934-14.

x. ICAO Doc. 8192 C/934-3. 
that many of the new States ${ }^{\text {k4 }}$ have filed instruments of acceptance of the International Air Services Transit Agreement ${ }^{89}$ in accordance with its Article VI (2) which provides that "any State a member of the International Civil Aviation Organization may accept the present Agreement". This implies that no State can become a party to this Agreement without also being a party to the Chicago Convention. The provision would, therefore, seem to apply directly to the new States. On the other hand, no new States appear to have accepted the International Air Transport Agreement, even though this was signed at Chicago on the same day and is governed by the same rules as apply to the acceptance of the International Air Services Transit Agreement.

Let us turn briefly to the practice of the new States with respect to the Warsaw Convention." Although this is one of the private air law conventions concerned with the Unification of Certain Rules Relating to International Carriage by Air, it was extended by the contracting Parties to all non-metropolitan territories. The Convention was signed at Warsaw on October 12, 1929. Article 40 states that (a) any contracting State may at the time of deposit of ratification or accession declare that its acceptance of the Convention "does not apply to all or any of its colonies, protectorates, territories under mandate, or any other territory subject to its sovereignty or its authority, or any territory under its suzerainty"; (b) any State may subsequently adhere separately to the Convention in respect of any or all of such colonies and territories; and (c) it may denounce the Convention separately for all or any of them. In view of the possibility of subsequent changes in the international status of dependent territories, a modified version of these rules was incorporated in Article 23 of the Convention on International Recognition of Rights in Aircraft, concluded at Geneva on June 19, 1949;:12 in Article 25 of the Protocol to Amend the Convention of the Unification of Certain Rules Relating to International Carriage by Air (the Warsaw Convention) signed at the Hague on September 28, 1955;:2 and in Article 16 of the Convention, Supplementary to the Warsaw Convention, for the Unification of Certain Rules Relating to International Carriage by Air Performed by a Person Other Than the Contracting Carrier, concluded at Guadalajara on September 18, 1961: The last two agreements are intended to amend as well as to supplement the Warsaw Convention of 1929 in order to bring it into line with the final clauses of that Convention relating to dependent territories. It is to be noted that the expression "High Contracting Parties" is used in the Warsaw Convention; therefore, in so far as the colonies were concerned, it was in Headof-State form, and was intended, for instance in the case of the British Empire, to apply to all of the colonies qua colonies. It will be recalled that in Philippson v. Imperial Airways Ltd." "' the British House of Lords held that the expression "High Contracting Parties" as used in the Warsaw Convention means "signatories". There is, however, room for doubt as to whether this was really a good decision. Nevertheless, from the point of view of State succession, this ruling raises the question

A* These are Cameroon. Ceylon, Cyprus, Israel. Ivory Coast. Malagasy Republic. Malaysla, Morocco, Niger. Nigeria, Pakistan. Senceal and Tunisia.

xy Concluded at Chicago on December 7, 1944.

jo L.N.T.S. Vol. 137, at 11: U.S.T.S. 876; Cmd. 4284.

"1 Mankiewlez, supra, n. 78 at 62 et. seq..

02 Annuaire Francais (1957), at 405.

:13 Mankiewicz, supra, n. 91.

I4 Philippson v. Imperial Airways Ltd. (1939) A.C. 332. 
whether the Warsaw Convention could be held to bind the new States who themselves were not "signatories". That is to say, are the new States signatories by succession, or is the expression to be regarded as applying only to the actual signatories? At least a representative of one of the new States has suggested, probably on the basis of this case, that the devolution agreements are legally deficient and that the new State signed them without experience. ${ }^{.55}$

In the opinion of Dr. Mankiewicz, for the reasons stated above, ${ }^{06}$ the Warsaw Convention, being a private air law convention, applies automatically to the new States. However, there is no international arbitral authority in support of the view that the convention is automatically applicable in any of the new States. ${ }^{9-}$ Yet, the great majority of the new States have willingly continued to apply the relevant air conventions. Congo (Brazzaville), Congo (Kinshasa), Ivory Coast, Niger, Mauritania, Laos, Malagasy Republic, Indonesia and Ceylon have all deposited declarations of succession; Israel, Pakistan, Philippines, Morocco, Mali and Guinea have chosen to adhere to the Convention. On the other hand; Dahomey has deposited an instrument of ratification of the Hague Protocol, 1955, and this, in effect, is equivalent to adhering to the Convention. It is true that even though they have chosen to continue the policies of their parent States with respect to international air conventions, the new States are also desirous of becoming their own flag-carriers. This may, in certain cases, lead to the imposition of some limitations upon foreign carriers. To some of the East African States, the whole notion of State succession is viewed with great caution, if not apprehension. This has accounted for the reserved attitude taken by such States as Tanzania, Uganda, Malawi, and even Kenya and Zambia. To these States, problems affecting succession to the treaty obligations of their predecessor are a matter within the political discretion of each State. Consequently, they have decided to subject all the relevant treaties to a careful review before declaring publicly their attitude to them. After its independence on October 9, 1962, Uganda announced that it was not quite certain whether or not to adhere to the Chicago Conventions. Its motive appeared to be thoroughly political, for Uganda was not prepared to co-operate with airlines of certain states whose domestic policies constituted a violation, in its view, of

95 Dr. T. O. Ellas in U.N. Doc. A/CN.4/SER. A/1952, at 4.

os Mankiewicz, supra, n. 78 at 62.

n: The continuity of the Warsaw Convention was tested in Dabrai v. Air India Ltd., in which the High Court of Bombay held that India was a "High Contracting Party" to the Warsaw Convention in so far as the Indian Independence Act, 1947, provided for a devolution of English law, and the Convention had been implemented by approprlate legislative action through the enactment of the Indian Carriage by Air Act. 1934. followed by the certification of the High Contracting Parties by the Governor-General in 1939 under the authority of the above Act (I.L.R., 1953, at 41). A similar question arose in the action brought by the French Treasury against Air Laos after the crash of a Laottan Airliner on June 16. 1953, on a flight from Vientlanne, the capital of Laos, to Saigon. The French Tribunal civil de la Seine, was to decide, in 1958 . whether Laos and Vietnam. which were formerly French Protectorates, remained bound by the Warsaw Convention by virtue of its ratification by France. The Tribunal decided that "there can be no doubt that Laos and Vietnam were and remain bound by the undertakings given in their name by France prior to their independence" in as much as the convention has not been formally denounced by elther State. The flight was held to be within the meaning of the expression "international carriage" and hence governed by the Warsaw Convention. See Tresor Public v. Cie Air Laos (1). (1958) Annuaire Francais de Convention. See Tresor Public v. Cie Air Laos (1). (1958) Annuaire

Article 1 of the Convention, amended by Article 1 of the Hague Protocol, 1955, defines "International carriage" to Include any carriage in which, according to the contract made by the parties. the place of departure and the place of destination are situated either within the territories of two High Contracting Parties, or within the territory of a single High Contracting Party. An agreed stopping place, even within the territory of a non-Contracting Party, is part of this definition. 
human rights. This would seem to suggest that, other things being equal, a new State might even be tempted to exploit its position vis-a-vis an existing treaty as a political weapon with which to pressure another State into modifying its domestic policy if such is found by the former to be distasteful.

\section{SUCCESSION TO MULTILATERAL INSTRUMENTS ADMIN- ISTERED BY OTHER INTERNATIONAL ORGANIZATIONS}

It is proposed to deal briefly in this section with the World Health Organization and the General Agreement on Tariffs and Trade (GATT) in order to show the general trend towards acceptance of the existing conventions by the new States.

The problem of succession to the international agreements administered by the WHO must be viewed in a special context since their practice is far less developed than that of the I.L.O., for instance. In other words, a new State is not made to declare itself bound by existing agreements of the WHO as a condition of admission to that Organization.

The WHO acts as the depositary of the International Sanitary Regulations of 1951. These were amended in 1955, 1956, 1960 and 1963. It further administers the Brussels Agreement, 1924, governing the granting of Facilities to Merchant Seamen for the Treatment of Venereal Disease. But Belgium acts as the depositary of this agreement. The Regulations No. 1 Regarding Nomenclature (including the Compilation and Publication of Statistics) with Respect to Diseases, adopted in 1948 and added to in 1956, is also administered by the Organization.

Membership in the Organization is open to all States, and members of the United Nations may become members of WHO merely by depositing instruments of acceptance with the Secretary-General of the United Nations. ${ }^{\circ 4}$ But States not members of the U.N. may apply directly to the Organization for membership, subject to the approval of the World Health Assembly. If admitted, such a State is then required to deposit a formal instrument of acceptance of the Constitution of the WHO with the Secretary-General of the United Nations."10

As regards the problem of succession, the Organization holds the view that the instruments of which it is the depositary remain binding on a new State after it achieves political autonomy. Nevertheless, the general practice is not to ask a new State to acknowledge continuity of such instruments on attaining independence. ${ }^{100}$ On the other hand, the attitude of the Organization respecting those instruments of which it is not the depositary, but which it administers, remains undefined. Broadly speaking, the assumption is that such agreements continue to apply unless and until a new State expressly denies their continuity. ${ }^{101}$ Morocco, which had been a French Protectorate, was affected by the Brussels Agreement of 1924 by virtue of France's signature. But on independence, Morocco decided to deposit a fresh instrument of accession with the Belgian Government. No comment was made on the Moroccan action. Burma has not, on the other hand, become a party to the International Sanitary Regulations of 1951 (as amended in 1955, 1956, 1960 and 1963);

ys See statement by the Chlef Legal Officer of WHO. I.L.A., Effect of Independence ขอ Id.

100 Id. at 329

101 Id., at 330 . 
in that case, the view of WHO remains that Burma continues to be bound by the Sanitary Convention of 1926 which was territorially applied to her. It would appear that Burma has acquiesced in this.

On the whole, the new States appear to have continued to apply all the agreements of which the Organization is the depositary. Information provided to the Organization by the new States regarding "quarantinable diseases" and action taken by them under the terms of Article 13 of the 1951 Regulations and Article 62 of the Constitution of the Convention, indicates that the overall attitude towards the enforcement of the prescribed regulations is favourable. It is conceivable that the obvious humanitarian character of these agreements may account for the markedly favourable disposition of the new States towards them.

The General Agreement on Tariffs and Trade is, strictly speaking, a multilateral treaty on international trade in which a large number of countries participate. It also forms the constituent instrument of that Organization. Its constitution clearly provides for succession on independence. Article XXVI: 5 (c) states:

If any of the customs territories, in respect of which a contracting party has accepted this Agreement, possesses or acquires full autonomy in the conduct of its external commercial relations and of the other matters provided for in this Agreement, such territory shall, upon sponsorship through a declaration by the responsible contracting party establishing the above-mentioned fact, be deemed to be a contracting party.

The colonial Powers had applied the GATT to all the non-metropolitan territories in accordance with the provisions of Article XXVI: 5(a) of the Constitution that "each Government accepting this Agreement does so in respect of its metropolitan territory and of the other territories for which it has international responsibility". The procedure set out in paragraph (c) of this article was followed in admitting new States until 1963 when the procedure was considerably simplified. Under the new rule, a new State that wishes to become a member only has to notify the Executive Secretary of GATT, who then undertakes to certify that the conditions stipulated under Article XXVI: 5(c) of the Constitution have been met, and the new State is henceforth declared to be a contracting party." While many of the new States ${ }^{10: 1}$ were admitted on independence as contracting parties, some have shown reluctance in participating in the GATT.

In 1960, it was decided that parties to the GATT should continue to apply the provisions of the GATT, on a reciprocal basis, in their trade with the new States, for two years, or, if requested, three years, from the date of independence. ${ }^{101}$ The majority of the new States were highly receptive to this offer, but some have shown a lukewarm enthusiasm towards it, even though in practice they are still applying the GATT. These States included Algeria, Congo (Kinshasa), Mali and Zambia. It should be noted that among the new States, Algeria is probably the only one that has attempted to remain faithful to its traditionally revolutionary principles. This attitude seems manifested in its outspoken dissatisfaction with certain elements of traditional international law. On this ground, it not only has decided against accepting the compulsory jurisdiction of the International Court of Justice under Article 36 of the

10: See GATT Doc. C/30 Restricted, April 26, 1963.

113 Ghana, Gambia, Indonesia. Kenya, Malawi. Malaysia, Malta, Nigeria, Tanzania, Jamaica. Trinidad, Tobago, Uganda and Zambia.

$10+$ I.L.A. Effect of Independence on Treaties, supra, n. 98 at 238. 
Statute, but in all multilateral treaties to which she has become a party, she has often added a reservation, particularly with regard to any provisions dealing with the peaceful settlement of disputes in accordance with procedures specified in the treaties. Similarly, in connection with the law of State succession, Algeria is one of the minority of States who believe that a new State should start life completely unencumbered by the treaty obligations of its predecessor. This policy attitude of the Algerian Government would seem to imply that Algeria wishes to remain the sole judge of whatever international obligations she wishes to accept.

The simplified procedure for admitting the new States to the GATT is designed to enable them to avoid the rather protracted process of negotiating for membership; furthermore, it is calculated to secure the maximum possible degree of continuity of the legal regime created by the GATT. But as is well-known, membership in any organization entails the acceptance of obligations and the enjoyment of certain rights by the members. Therefore, by accepting the status of contracting parties, the new States have in effect accepted the obligations formerly assumed on their behalf by their parent States. The rights and duties embodied in the GATT fall into four categories: (a) trade must remain non-discriminatory, and the contracting parties are urged to apply the most favoured nation principle; (b) protection of domestic industries is to be achieved only by customs tariffs rather than by other arbitrary methods; (c) a system of consultations shall be maintained between members; and (d) GATT shall furnish the framework within which negotiations can be undertaken with a view to the reduction of tariffs and other barriers to trade, and a structure for incorporating such negotiations into a legal instrument. There is little doubt that the ideals underlying these principles are in themselves attractive since they are designed to stabilize international commercial relations.

It can be said, however, having regard to its very structure and purpose, that the GATT has been a hotbed of acute political and economic conflicts between the developed, industrialized nations and the underdeveloped, agricultural Statts, the preponderant majority of which are the new States. In participating in the GATT, each State's evaluation of its economic and political interests tends to overshadow the desire to develop or adopt rules of law which will comprehend the common interest of all the States. The new States tend to utilize their common element of poverty as the basic criterion of unity against the powerful, industrialized States.

In 1963, a number of the newly independent States adopted at their ministerial meeting a programme, calling upon the industrialized nations to reduce trade barriers and expand the access to industrial markets of exports from the developing countries. The new States appear to be sensitive to the dominating role of the industrialized states in the GATT; and the fact that they are producers of primary commodities, often at the mercy of fluctuating world prices, makes them implicitly distrustful of the GATT. They seem to believe that reduction of tariffs as envisaged by GATT stands to benefit the industrial nations, since their products do not have equal access to the markets of those countries. At the United Nations Conference on Trade and Development, held at Geneva in 
March to June, 1964, the new States' distrust of the GATT came to a head and resulted in proposals by some of these States, supported by the Soviet Union, that a new trade organization should be established to replace the GATT. However, these proposals were rejected.

The foregoing analysis would seem to illustrate the peculiar extent to which economic, political, and perhaps strategic considerations may influence a State's attitude and ultimate action even in the matter of succession to multilateral conventions. For while the importance of many multilateral conventions is generally recognized, and the new States for the most part are willing to assume the obligations stipulated under such relevant conventions as are acknowledged to be binding, chiefly on grounds of economic and administrative convenience, their overall practice reveals consistent reluctance to act in a manner liable to be construed as confirmatory of the principle of universal or automatic succession. Their insistence upon retaining the right of option with respect to certain types of multilateral instruments and, in some instances, their actual acceptance of succession on a selective basis, derive to a considerable extent from differences in the subjective perception of their national interests, which are in turn conditioned by the larger issues of politics and ideology. 